\title{
STRATEGI PEMASARAN PRODUK GADAI SYARIAH DALAM UPAYA MENARIK MINAT NASABAH PADA PEGADAIAN SYARIAH
}

\author{
Faridatun Sa'adah \\ STAI Al-Muhlisin Ciseeng Bogor \\ Email: faridass@yahoo.com
}

\begin{abstract}
Abstrak: Islam merupakan suatu sistem dan jalan hidup yang utuh dan terpadu, Islam memberikan panduan yang dinamis terhadap semua aspek kehidupan termasuk sektor bisnis dan transaksi keuangan. Hal ini terlihat dengan menggunakan prinsip syariah, karena diharapkan dengan menggunakan prinsip syariah Islam dapat memberikan mashlahat bagi umat manusia dan salah satu kelebihan dari lembaga keuangan syariah adalah tidak boleh meminta kelebihan dari pokok pinjaman, karena hal yang demikian itu termasuk riba. Sebagaimana kita ketahui bahwa riba didalam Islam itu sangatlah diharamkan. Perkembangan lembaga-lembaga keuangan Islam di Indonesia dapat dikategorikan cepat dan yang menjadi salah satu faktor tersebut adalah adanya keyakinan pada masyarakat muslim bahwa perbankan konvensional itu mengandung unsur riba yang dilarang oleh agama Islam.
\end{abstract}

Kata Kunci: Strategi, Pemasaran, Nasabah Bank

\section{Pendahuluan}

Manusia sebagai makhluk hidup, tidak akan bisa terlepas dari kegiatankegiatan yang berorientasi pada aspek pemenuhan kebutuhan hidup sehari-hari (ekonomi). Ilmu ekonomi lahir bertujuan untuk membantu manusia dalam pemenuhan kebutuhannya. Dalam ilmu ekonomi dipelajari pemanfaatan suatu benda secara efektif dan efisien, dipelajari pula bagaimana mengelola keuangan dengan baik.

Islam merupakan suatu sistem dan jalan hidup yang utuh dan ter- 
padu, Islam memberikan panduan yang dinamis terhadap semua aspek kehidupan termasuk sektor bisnis dan transaksi keuangan. Hal ini terlihat dengan menggunakan prinsip syariah, karena diharapkan dengan menggunakan prinsip syariah Islam dapat memberikan mashlahat bagi umat manusia dan salah satu kelebihan dari lembaga keuangan syariah adalah tidak boleh meminta kelebihan dari pokok pinjaman, karena hal yang demikian itu termasuk riba. Sebagaimana kita ketahui bahwa riba didalam Islam itu sangatlah diharamkan. Perkembangan lembaga-lembaga keuangan Islam di Indonesia dapat dikategorikan cepat dan yang menjadi salah satu faktor tersebut adalah adanya keyakinan pada masyarakat muslim bahwa perbankan konvensional itu mengandung unsur riba yang dilarang oleh agama Islam. ${ }^{1}$

Namun hendaknya kita tidak mengabaikan salah satu lembaga lainnya di tengah perkembangan lembaga keuangan ini. Lembaga keuangan itu adalah pegadaian. Perum Pegadaian merupakan salah satu badan usaha di Indonesia yang secara resmi mempunyai ijin untuk melaksanakan kegiatan lembaga keuangan berupa pembiayaan dalam bentuk penyaluran dana ke masyarakat atas dasar hukum gadai. ${ }^{2}$

Pegadaian merupakan tempat bagi konsumen untuk meminjam uang dengan barang-barang pribadi konsumen sebagai jaminannya. Mengusung slogan “ Mengatasi Masalah Tanpa Masalah", Perum Pegadaian bahkan dinilai sebagai ekonomi kerakyatan. ${ }^{3}$ Hal ini didasarkan pada kenyataan bahwa masyarakat kelas bawah pun bisa memanfaatkan jasa gadai dari perum pegadaian ini.

Pegadaian merupakan salah satu alternatif pendanaan yang sangat efektif karena tidak memerlukan persyaratan rumit yang dapat menyulitkan nasabah dalam pemberian dana. ${ }^{4}$ Cukup dengan membawa barang

\footnotetext{
${ }^{1}$ Zainul Arifin, Dasar-dasar Manajemen Bank Syariah, (Jakarta: Alvabet, 2002), h. 8.

${ }^{2}$ Heri Sudarsono, Bank dan Lembaga Keuangan Syariah , (Yogyakarta: Ekonisia, 2003), h. 153.

3 “ Gadai Emas bank Syariah: Barang Aman, Uang di Tangan ", http: //www.prospektif. com/ terkini/ artikel. Html?id=969, 1 November 2002.

${ }^{4}$ Muhammad Firdaus NH, dkk, Mengatasi Masalah Dengan Pegadaian Syariah, (Jakarta: Renaisan, 2005), h. 13.
} 
jaminan yang bernilai ekonomis, masyarakat sudah bisa mendapatkan dana untuk kebutuhannya, baik produktif maupun konsumtif. Di samping itu proses pencairan dana yang terbilang cepat dan mudah. Pada masa krisis Perum Pegadaian mendapat peluang untuk semakin berperan dalam pembiayaan, khususnya untuk usaha kecil, dan ternyata selama kurun waktu krisis ekonomi nasional tersebut, Perum Pegadaian dapat menunjukkan kinerja yang memuaskan dan menjadi salah satu perusahaan yang tidak begitu berpengaruh oleh krisis. ${ }^{5}$

Akan tetapi konsep operasional pegadaian pun juga menggunakan sistem bunga yang memang sangat dilarang dalam syariah Islam. Praktek ini dapat dilihat ketika nasabah yang meminjam uang yang menggadaikan barangnya dibebankan untuk mengembalikan pokok pinjaman plus sewa modal (bunga). Bunga di pegadaian dihitung per 15 hari, dan apabila ada keterlambatan maka nasabah dibebankan untuk membayar bunga dua kali lipat, dan begitu seterusnya per 15 hari.

Namun hal itu tidak perlu dikhawatirkan lagi, karena sekarang ini selain terdapat pegadaian konvensional, beroperasi pula pegadaian syariah yang memang didirikan oleh Perum Pegadaian. Pengembangan konsep syariah ini merupakan upaya pegadaian untuk menghindari rente atau riba.

Keberadaan pegadaian syariah pada awalnya didorong oleh perkembangan dan keberhasilan lembaga-lembaga keuangan syariah. Di samping itu juga dilandasi oleh kebutuhan masyarakat Indonesia terhadap hadirnya sebuah pegadaian yang menerapkan prinsip-prinsip syariah.

Implementasi operasional pegadaian syariah hampir mirip dengan pegadaian konvensional. Seperti halnya pegadaian konvensional, pegadaian syariah juga menyalurkan uang pinjaman dengan jaminan barang bergerak. Nasabah dapat memperoleh dana yang diperlukan dalam waktu yang relatif cepat, proses administrasi dan penaksiran hanya lebih kurang 15 menit, dan dana pinjaman dapat diterima nasabah kurang dari 1 jam.

Meski baru seumur jagung, pertumbuhan pegadaian syariah ternyata bisa mengimbangi industri perbankan Islam di Indonesia. Karena selain pegadaian syariah, pemain dalam usaha ini adalah perbankan syariah yang

${ }^{5}$ Frianto Pandia, dkk, Lembaga Keuangan, (Jakarta: Rineka Cipta, 2005), h. 69. 
menyediakan layanan berupa gadai syariah atau yang biasa disebut rahn. Namun dalam perjalanannya, pegadaian syariah tidak terlalu berpengaruh oleh beroperasinya sistem gadai syariah dari perbankan syariah. Ini terbukti dengan pertumbuhan yang signifikan dari segi omzet. Kenaikan tersebut adalah sebesar 123,84 \% dari Rp.19 miliar pada Desember 2003 menjadi Rp. 179,68 miliar pada Desember 2004. ${ }^{6}$ Minat masyarakat yang memanfaatkan jasa pegadaian syariah cukup besar. Pegadaian syariah tidak menekankan pada pemberian bunga dari barang yang digadaikan. Meski tanpa bunga, pegadaian syariah tetap memperoleh keuntungan seperti yang sudah diatur oleh Dewan Syariah Nasional, yang memberlakukan biaya pemeliharaan dari barang yang digadaikan. Biaya itu dihitung dari nilai barang, bukan dari jumlah pinjaman.

Suatu perusahaan yang bergerak dalam bidang apapun baik yang berorientasi terhadap perolehan laba jangka panjang maupun perusahaan nirlaba membutuhkan apa yang disebut dengan pemasaran. Pemasaran adalah suatu proses sosial dan melalui proses itu individu dan kelompok akan memperoleh apa yang mereka butuhkan dan inginkan dengan cara menciptakan dan mempertukarkan produk dan nilai dengan individu dan kelompok lain.

Pada umumnya masyarakat tidak memahami pemasaran, mereka melihat pemasaran sebagai sebuah penjualan. Padahal pemasaran ini mempunyai arti lebih luas karena pemasaran adalah suatu proses yang teratur dan jelas untuk memikirkan dan merencanakan pasar. Proses pemasaran dapat diterapkan tidak sekedar pada barang dan jasa, tetapi juga pada segala sesuatu yang dapat dipasarkan seperti ide, kejadian, organisasi, tempat dan kepribadian. Namun penting untuk ditekankan bentuk pemasaran tidak dimulai dengan suatu produk atau penawaran, tetapi dengan pencarian peluang pasar. ${ }^{7}$

Menurut M. Syakir Sula ada 4 karakteristik syariah marketing yang dapat menjadi panduan bagi pemasar, yakni teistis (rabbaniyyah), etis

6 "Pertumbuhan Pegadaian Syariah Memuaskan", http://www.republika.co.id/koran detail.asp?id=183268 \& kat id 2=, 8 Januari 2005.

${ }^{7}$ Hendra, dkk, Manajemen Pemasaran: Analisis, Perencanaan, Implementasi dan Kontrol, (Jakarta: PT Prenhallindo, 1997), Jilid I, h. 18. 
(akhlaqiyyah), realistis (al-waqi'iyyah), dan humanistis (insaniyyah). Inilah yang membedakan sistem ekonomi Islam dengan sistem ekonomi konvensional. Yang menarik pemasaran syariah meyakini bahwa perbuatan yang dilakukan seseorang akan dimintai pertanggungjawabannya kelak. Selain itu, pemasaran syariah mengutamakan nilai-nilai akhlak dan etika moral di dalam pelaksanaannya. Karena itu pemasaran syariah menjadi penting bagi para tenaga pemasaran untuk melakukan penetrasi pasar. ${ }^{8}$

Strategi pemasaran antara konvensional dengan yang Islami tentulah berbeda dalam prosesnya, akan tetapi mempunyai tujuan yang sama yaitu bagaimana meningkatkan jumlah nasabah. Maju atau mundurnya perusahaan dapat dilihat dari strategi pemasaran mereka yang berdampak pada meningkatnya minat nasabah sehingga dapat meningkatkan jumlah nasabah dalam menggunakan produk jasa yang dikeluarkan oleh perusahaan, atau dengan kata lain, dapat meningkatkan volume penjualan, sehingga pemasaran yang baik akan berdampak signifikan terhadap pendapatan perusahaan.

Sehubungan dengan berkembangnya dunia pemasaran yang menimbulkan makin tingginya tingkat persaingan antara perusahaan-perusahaan di Indonesia, maka perusahaan-perusahaan tersebut semakin berusaha untuk memperkuat strategi pemasarannya. Untuk dapat bertahan dalam dunia bisnis yang kondisi persaingannya terus meningkat maka suatu perusahaan harus dituntut dapat menguasai pasar dengan menggunakan produk yang telah dihasilkan.

Dewi Sartika adalah daerah yang terletak di Jakarta timur yang merupakan daerah yang Islami karena dikelilingi oleh beberapa mesjid besar dan sekolah-sekolah Islam. Oleh karena itu keberadaan Pegadaian Syariah sangat membantu para masyarakat yang mayoritas muslim untuk dapat melakukan transaksi gadai tanpa adanya unsur riba di dalamnya.

Seperti kita ketahui, pengetahuan masyarakat tentang keberadaan pegadaian syariah masih minim karena pegadaian syariah terbilang masih baru dan kantor cabang syariahnya pun masih terbilang sedikit, tetapi

\footnotetext{
${ }^{8}$ Hermawan Kartajaya dan M. Syakir Sula, Syariah Marketing, (Bandung: Mizan, 2006),
} h. 28 . 
pertumbuhan pegadaian syariah menunjukkan peningkatan yang pesat, sehingga penulis ingin mengetahui strategi pemasaran apa yang digunakan oleh pegadaian syariah atas produk gadai syariah sehingga tumbuh menjadi pesat dan dapat menarik minat nasabah dalam menggunakan jasa tersebut. Dalam menarik minat nasabah memang tidak hanya dipengaruhi oleh strategi pemasaran yang digunakan oleh pegadaian syariah. Ada beberapa faktor lain yang mempengaruhinya seperti kebutuhan nasabah yang mendesak yang memerlukan proses pencairan dana yang cepat, nasabah yang menginginkan transaksi gadai tanpa adanya unsur ribawi (bunga) di dalamnya, dan lain sebagainya.

\section{Segmenting, Targeting, dan Positioning}

Segmentasi pasar adalah membagi pasar menjadi kelompok pembeli yang terbedakan dengan kebutuhan, karakteristik, atau tingkah laku berbeda yang mungkin membutuhkan produk atau bauran pemasaran terpisah. ${ }^{9}$

Dalam praktiknya segmentasi pasar terdiri dari segmentasi pasar konsumen dan segmentasi pasar industrial. Setiap segmen memiliki variabel tertentu, namun pada dasarnya variabel yang digunakan tidak jauh berbeda.

Variabel utama yang mungkin dipergunakan dalam segmentasi pasar konsumen adalah: ${ }^{10}$ Segmentasi Geografik, yaitu membagi pasar menjadi beberapa unit secara geografik atau membagi pasar berdasarkan wilayah tertentu, seperti Negara, regional, kota, kabupaten, kecamatan, atau lainnya. Segmentasi Demografik, yaitu membagi pasar berdasarkan kependudukan secara umum seperti, umur, jenis kelamin, ukuran keluarga, pendapatan, pekerjaan, agama, ras, dan kebangsaan. Segmentasi Psikografik, yaitu membagi pasar menjadi kelompok berbeda berdasarkan pada karakteristik kelas sosial, gaya hidup, atau kepribadian. Segmentasi Tingkah Laku, yaitu mengelompokkan pembeli berdasarkan pada pengetahuan, sikap, penggunaan, atau reaksi mereka terhadap suatu produk. Segmentasi Manfaat, yaitu membagi pasar menjadi kelompok menurut beraneka manfaat berbeda yang dicari konsumen dari produk.

\footnotetext{
${ }^{9}$ Ibid., h. 235.

${ }^{10}$ Kasmir, Pemasaran Bank, (Jakarta: Kencana, 2004), h. 115-116.
} 
Sedangkan variabel untuk melakukan segmentasi pasar industrial adalah: ${ }^{11}$ Segmentasi berdasarkan demografik yaitu: jenis industri, ukuran perusahaan, lokasi perusahaan, dan lainnya. Karakteristik pengoperasian, yaitu: teknologi yang difokuskan, gaya hidup, status pengguna, kepribadian, atau lainnya. Pendekatan pembeli, yaitu: sifat hubungan yang ada, kriteria pembeli, atau lainnya. Karakteristik Personil Industri, yaitu: kesamaan pembeli, kesetiaan, sikap terhadap resiko, atau lainnya. Faktor situsional, seperti: urgensi, besarnya pesanan, atau lainnya.

Segmentasi pasar perlu dilakukan oleh suatu perusahaan karena di dalam suatu pasar terdapat banyak pembeli yang berbeda kebutuhan dan keinginannya. Jadi, segmentasi pasar pada perusahaan dibuat bertujuan untuk dapat mengungkap peluang segmen pasar sebuah perusahaan. Sehingga perusahaan dapat mengetahui segmen pasar mana yang paling efektif.

\section{Menentukan Sasaran Pasar (Targeting)}

Setelah perusahaan selesai melakukan segmentasi pasar, maka langkah selanjutnya adalah menentukan sasaran pasar. Menentukan sasaran pasar, artinya mengevaluasi keaktifan setiap segmen, kemudian memilih salah satu dari segmen pasar atau lebih untuk dilayani. Menetapkan pasar sasaran dengan cara mengembangkan ukuran-ukuran dan daya tarik segmen kemudian memilih segmen sasaran yang diinginkan. ${ }^{12}$

Kegiatan menetapkan pasar sasaran adalah: ${ }^{13}$ Pertama, Evaluasi Segmen Pasar, meliputi: ukuran dan pertumbuhan segmen seperti data tentang usia nasabah, pendapatan, jenis kelamin, atau gaya hidup dari setiap segmen. Struktural segmen yang menarik dilihat dari segi profitabilitas. Kurang menarik jika terdapat pesaing yang kuat dan agresif. Perhatikan juga ancaman dari produk pengganti (substitusi) misalnya dari lembaga keuangan lainnya, untuk pinjaman seperti bank, kantor pos dan giro, leasing atau money changer. Sasaran dan sumber daya perusahaan dengan

\footnotetext{
${ }^{11}$ Ibid., h. 116-117.

${ }^{12}$ Ibid., h. 118-119.

${ }^{13}$ Ibid., h. 119.
} 
memperhatikan energi yang dimiliki perusahaan yaitu ketersediaan sumber daya manusia termasuk keterampilan yang dimilikinya.

Kedua, Memilih Segmen. Memilih segmen adalah menentukan satu atau lebih segmen yang memiliki nilai tinggi bagi perusahaan. Kemudian menentukan segmen mana dan berapa banyak yang dapat dilayani. Pemilihan segmen dapat dilakukan dengan cara membagi pemasaran menjadi: ${ }^{14}$

Pemasaran tanpa pembedaan, melayani semua pasar dan tawaran pasar dalam arti tidak ada perbedaan. Mencari apa yang sama dalam kebutuhan konsumen. Biasanya untuk produk massal seperti tabungan untuk semua orang, baik usia, pendapatan, maupun wilayah. Keuntungan pemasaran tanpa pembedaan adalah hemat biaya Pemasaran dengan pembedaan, strategi peliputan pasar dimana sebuah perusahaan memutuskan untuk memilih beberapa segmen pasar dan merancang barang yang berbeda untuk masing-masing segmen. Contohnya Procter dan Gamble memperoleh pangsa pasar total yang lebih tinggi dengan sebelas merk deterjen pencuci pakaian dibandingkan dengan hanya satu merk deterjen saja. Strategi ini jelas memerlukan biaya yang lebih tinggi. ${ }^{15}$

Pemasaran terkonsentrasi, strategi peliputan pasar dimana sebuah perusahaan memutuskan untuk mencari pangsa pasar besar dalam satu atau beberapa sub pasar. Pemasaran terkonsentrasi, khusus untuk sumber daya manusia yang terbatas. Menentukan sasaran pasar dilakukan dengan cara mengevaluasi segmen pasar, setelah dievaluasi kemuadian langkah selanjutnya yaitu memilih segmen pasar berdasarkan apakah pemasaran perusahaan tersebut cocok dengan pemasaran tanpa pembeda, pemasaran dengan pembeda, atau pemasaran terkonsentrasi.

\section{Menentukan Posisi Pasar (Positioning)}

Menentukan posisi pasar yaitu menentukan posisi yang kompetitif untuk produk atau suatu pasar. Produk atau jasa diposisikan pada posisi yang diinginkan oleh nasabah, sehingga dapat menarik minat nasabah untuk

\footnotetext{
${ }^{14}$ Kasmir, Pemasaran Bank.h. 119.

${ }^{15}$ Kotler dan Armstrong, Dasar-dasar Pemasaran, h. 252.
} 
membeli produk atau jasa yang ditawarkan. Kegiatan ini dilakukan setelah menentukan segmen mana yang akan dimasuki dengan cara menentukan di mana posisi mana yang ingin ditempati dalam segmen tersebut. ${ }^{16}$

Memilih dan melaksanakan strategi penentuan posisi pasar perlu dilakukan dengan berbagai tahap agar hasil yang diharapkan optimal. Tahapan dalam memilih dan melaksanakan strategi penentuan posisi pasar sebagai berikut:

Pertama, Identifikasi Keunggulan Kompetitif. Di dalam suatu produk terdapat berbagai keunggulan jika dibandingkan dengan produk pesaing. Tujuan manajemen mengidentifikasikan keunggulan tersebut sebanyak dan selengkap mungkin. Identifikasi keunggulan kompetitif yang mungkin memberikan nilai yang terbesar dengan cara mengadakan perbedaan, yaitu: (1) Diferensiasi produk; Sebuah perusahaan dapat mendiferensiasikan produk secara fisik. Contohnya, beberapa perusahaan menawarkan produk dengan standar tinggi yang hanya memungkinkan sedikit variasi. ${ }^{17}$ (2) Diferensiasi jasa; Beberapa perusahaan memperoleh keunggulan bersaing lewat penyerahan yang cepat, nyaman, atau cermat. Contohnya, Bank One telah membuka cabang di toserba dengan pelayanan lengkap untuk menyediakan lokasi yang mudah dijangkau di hari Sabtu, Minggu, dan di sore hari pada hari kerja. ${ }^{18}$ (3) Diferensiasi personil; Perusahaan dapat meraih keunggulan yang sangat bersaing lewat mempekerjakan dan melatih orang yang lebih baik ketimbang yang bekerja di perusahaan pesaing. Contohnya, Singapore Airlines menikmati reputasi luar biasa karena keramahan pramugari dan pramugara. ${ }^{19}$ (4) Diferensiasi citra; Ketika pesaing menawarkan bentuk yang serupa, pembeli mungkin menganggap berbeda berdasarkan pada citra perusahaan atau merek. Contohnya, lengkung emas Mc. Donals. ${ }^{20}$

Kedua, Memilih Keunggulan Kompetitif yang Tepat. Setelah diidentifikasikan keunggulan-keunggulan yang kompetitif, lalu langkah selanjut-

\footnotetext{
${ }^{16}$ Kasmir, Pemasaran Bank, h. 121.

${ }^{17}$ Kotler dan Armstrong, Dasar-dasar Pemasaran, h. 256.

${ }^{18}$ Ibid.

${ }^{19}$ Ibid., h. 257.

${ }^{20}$ Ibid., h. 257-258.
} 
nya adalah dipilih yang paling memberikan keunggulan yang paling banyak. Pertimbangan pemilihan keunggulan kompetitif adalah berapa banyak perbedaan yang dipromosikan. Banyak pemasar berpendapat bahwa perusahaan harus secara agresif mempromosikan hanya satu manfaat kepada pasar sasaran. Tokoh periklanan Rosser Reeves, misalnya, mengatakan sebuah perusahaan harus mengembangkan Unique Selling Proposition (USP, proposisi penjualan yang unik) untuk setiap merek dan tetap berpegang pada proposisi itu. Setiap merek harus mengambil satu atribut dan menyatakan dirinya sebagai "nomor satu" pada atribut tersebut. ${ }^{21}$

Kemudian Perbedaan mana yang dipromosikan. Tidak semua pembedaan merk itu berarti atau cukup bernilai. Tidak setiap perbedaan dapat menjadi pembeda yang baik. Setiap perbedaan mempunyai potensi untuk menimbulkan biaya bagi perusahaan dan manfaat bagi pelanggan. Suatu perbedaan itu bernilai jika memenuhi kriteria berikut ini: (1) Penting: Perbedaan memberikan suatu manfaat yang sangat bernilai bagi pembeli sasaran. (2) Khas: Perusahaan dapat menawarkan dengan cara yang khas. (3) Terjangkau harganya: Pembeli dapat membayar perbedaan itu. (4) Dapat dikomunikasikan: Perbedaan itu dapat dikomunikasikan dan dapat dilihat oleh pembeli. ${ }^{22}$

Ketiga, Mewujudkan dan Mengkomunikasikan Posisi yang Dipilih. Posisi pasar yang telah di pilih sebaiknya diwujudkan, kemudian dikomunikasikan ke berbagai pihak yang membutuhkan termasuk pihak intern perusahaan. ${ }^{23}$

Dalam menentukan posisi pasar, produk atau jasa suatu perusahaan ditempatkan pada posisi yang banyak diinginkan oleh nasabah. Dalam menentukan posisi pasar mengidentifikasi keunggulan produk yang dimiliki merupakan langkah awal dalam menentukan posisi pasar dengan menggunakan diferensiasi produk, jasa, personil, atau citra. Langkah selanjutnya adalah memilih keunggulan kompetitif yang tepat dengan per-

\footnotetext{
${ }^{21}$ Ibid., h. 258.

22 Ibid., h. 259.

${ }^{23}$ Kasmir, Pemasaran Bank, h. 123.
} 
timbangan berapa banyak perbedaan yang dipromosikan atau perbedaan mana yang dipromosikan. Dan langkah terakhir dalam penentuan posisi pasar adalah mewujudkan dan mengkomunikasikan posisi yang di pilih.

\section{Bauran Pemasaran (Marketing Mix)}

Dalam dunia pemasaran selalu terkait dengan yang dinamakan marketing mix (bauran pemasaran). Marketing mix adalah deskripsi dari suatu kumpulan alat-alat yang dapat digunakan oleh manajemen untuk mempengaruhi penjualan. ${ }^{24}$

Kotler dan Armstrong mendefinisikan bauran pemasaran sebagai perangkat alat pemasaran taktis yang dapat dikendalikan, yang dipadukan oleh perusahaan untuk menghasilkan respons yang diinginkan dalam pasar sasaran. Bauran pemasaran terdiri dari segala sesuatu yang dapat dilakukan perusahaan untuk mempengaruhi permintaan produknya. Kemungkinan yang banyak itu dapat digolongkan menjadi empat kelompok variabel yang dikenal sebagai "empat P": Product, Price, Place, dan Promotion (produk, harga, distribusi, promosi). ${ }^{25}$ Empat $\mathrm{P}$ dalam marketing mix yaitu:

Pertama, product (produk). Menurut Philip Kotler "Produk adalah sesuatu yang dapat ditawarkan ke pasar untuk mendapatkan perhatian untuk dibeli, untuk digunakan, atau untuk dikonsumsi yang dapat memenuhi keinginan dan kebutuhan." ${ }^{26}$ Dalam definisi secara luas produk meliputi objek secara fisik, jasa, orang, tempat, organisasi, ide, atau bauran dari semua bentuk-bentuk tadi.

Dari pengertian di atas dapat disimpulkan bahwa produk adalah sesuatu yang memberikan manfaat baik dalam hal memenuhi kebutuhan sehari-hari atau sesuatu yang ingin dimiliki oleh konsumen. Produk biasanya digunakan untuk dikonsumsi baik untuk kebutuhan rohani maupun jasmani. Untuk memenuhi keinginan dan kebutuhan akan produk, maka konsumen harus mengorbankan sesuatu sebagai balas

${ }^{24}$ Firdaus NH dkk, Dasar \& Strategi Pemasaran Syariah, (Jakarta: Renaisan, 2005), h. 22.

${ }^{25}$ Kotler dan Armstrong, Dasar-dasar Pemasaran, h. 48.

${ }^{26}$ Kotler dan Armstrong, Prinsip-prinsip Pemasaran, (Jakarta: Erlangga, 2001), Jilid I ed. Ke-8 h. 346. 
jasanya. Dalam perspektif syariah produksi merupakan sesuatu yang penting. Al-Qur'an menggunakan konsep produksi barang dalam arti yang sangat luas. Tekanan Al-Qur'an diarahkan pada manfaat dari barang yang diproduksi. Memproduksi suatu barang harus mempunyai hubungan dengan kebutuhan hidup manusia. Berarti barang itu harus diproduksi untuk kebutuhan manusia, bukan untuk memproduksi barang-barang mewah secara berlebihan yang tidak sesuai dengan kebutuhan manusia. ${ }^{27}$

Islam juga mengajarkan untuk memperhatikan kualitas dan keberadaan produk tersebut. Islam melarang jual beli suatu produk yang belum jelas (gharar) bagi pembeli. Pasalnya di sini berpotensi terjadinya penipuan dan ketidakadilan terhadap salah satu pihak. Selain keberadaan suatu produk, Islam juga memerintahkan untuk memperhatikan kualitas produk. Barang yang dijual harus terang dan jelas kualitasnya, sehingga pembeli dapat dengan mudah memberi penilaian. ${ }^{28}$

Dari uraian di atas dapat penulis simpulkan bahwa produk dalam perspektif syariah (fiqh muamalah) harus memenuhi standarisasi mutu dan keberadaan barang. Fiqh muamalah tegas mengharamkan praktik jual beli yang menipu dengan ketidakjelasan mutu dan keberadaan barang.

Setiap produk yang diluncurkan ke pasar tidak selalu mendapat respon yang positif. Bahkan cenderung mengalami kegagalan jauh lebih besar dibandingkan keberhasilannya. Untuk mengantisipasi agar produk yang diluncurkan berhasil sesuai dengan tujuan yang diharapkan, maka peluncuran produk diperlukan strategi-strategi tertentu. Khusus dengan yang berkaitan dengan produk , strategi ini kita kenal dengan nama strategi produk. ${ }^{29}$

Dalam strategi produk yang harus dilakukan untuk mengembangkan suatu produk adalah: (1) Penentuan logo dan moto. Logo merupakan ciri khas suatu perusahaan sedangkan moto merupakan serangkaian katakata yang berisi visi dan misi. (2) Menciptakan merk. Karena jasa memiliki beraneka ragam, maka setiap jasa harus memiliki nama. Tujuannya agar

\footnotetext{
${ }^{27}$ Firdaus, Dasar \& Strategi Pemasaran Syariah, h. 23.

${ }^{28}$ Ibid.

${ }^{29}$ Kasmir, Pemasaran Bank, h. 141.
} 
mudah dikenal dan diingat. (3) Menciptakan kemasan. Kemasan merupakan pembungkus suatu produk. Dalam hal ini kemasan lebih diartikan kepada pemberian pelayanan atau jasa kepada para nasabah. ${ }^{30}$

Dalam strategi produk, perusahaan harus dapat melihat produk apa yang lebih dibutuhkan dan diinginkan oleh pembeli sehingga perusahaan dapat memperoleh banyak nasabah. Selain itu kualitas dan keberadaan produk juga harus diperhatikan sehingga tidak berpotensi terjadi penipuan.

Kedua, price (harga). Harga adalah jumlah uang yang harus dibayar oleh pelanggan untuk memperoleh suatu produk. ${ }^{31}$ Dalam konsep Islam, penentuan harga ditentukan oleh mekanisme pasar, yakni bergantung pada kekuatan-kekuatan permintaan dan penawaran. Dan pertemuan antara permintaan dan penawaran itu harus berlangsung secara sukarela. Ini bermakna tidak ada yang menganiaya dan dizalimi. Dalam praktik fiqh muamalah, harga mengambil posisi tengah, tidak berlebih-lebihan, tidak pula merendah-rendahkan. Ini berarti bahwa dalam praktik fiqh muamalah harga mestinya harus proporsional. ${ }^{32}$

Tujuan penentuan harga secara umum adalah: Pertama, Untuk Bertahan Hidup. Artinya, dalam kondisi tertentu, terutama dalam kondisi persaingan yang tinggi. Dalam hal ini perusahaan menentukan harga semurah mungkin dengan maksud produk atau jasa yang dipasarkan laku dipasaran. Kedua, Untuk Memaksimalkan Laba. Tujuan harga ini dengan mengharapkan penjualan yang meningkat sehingga laba dapat ditingkatkan. Penentuan harga biasanya dapat dilakukan dengan harga murah atau tinggi. Ketiga, Untuk Memperbesar Market Share. Penentuan harga ini dengan harga yang murah, sehingga diharapkan jumlah nasabah meningkat dan diharapkan pula nasabah pesaing beralih ke produk yang ditawarkan. Keempat, Mutu Produk. Tujuan dalam hal mutu produk adalah untuk memberikan kesan bahwa produk atau jasa yang ditawarkan memiliki kualitas yang tinggi dan biasanya harga ditentukan setinggi mungkin. Kelima, Karena Pesaing. Dalam hal ini, penentuan harga dengan melihat

\footnotetext{
${ }^{30}$ Ibid., h. 141-143.

${ }^{31}$ Kotler dan Armstrong, Prinsip-prinsip Pemasaran, h. 48.

${ }^{32}$ Firdaus, Dasar \& Strategi Pemasaran Syariah, h. 24-25.
} 
harga pesaing. Tujuannya adalah agar harga yang ditawarkan jangan melebihi harga pesaing. ${ }^{33}$

Strategi harga yang dilakukan perusahaan adalah strategi kedua pada bauran pemasaran. Dimana perusahaan sebisa mungkin menawarkan harga yang terendah sehingga lebih banyak menarik minat nasabah. Tetapi dalam Islam harga haruslah proporsional tidak boleh terlalu tinggi tidak boleh juga terlalu rendah.

Ketiga, place (distribusi). Dalam sektor jasa, distribusi didefinisikan sebagai setiap sarana yang meningkatkan keberadaan atau kenikmatan suatu jasa yang menambah penggunaannya atau pendapatan dari penggunaannya, baik dengan mempertahankan pemakai yang ada, meningkatkan nilai kegunaannya diantara pemakai yang ada ataupun menarik pemakai baru. ${ }^{34}$ Sarana-sarana tersebut dapat berupa kantor pusat, kantor cabang, , dan lain-lain yang dapat memudahkan nasabah untuk memperoleh manfaat dari jasa perusahaan tersebut.

Distribusi termasuk aktivitas perusahaan untuk membuat produk tersedia bagi konsumen sasaran. Setiap perusahaan haruslah memiliki pandangan saluran distribusi keseluruhan terhadap masalah distribusi dari produknya ke pemakai akhir. Dalam usaha untuk mencapai tujuan dan sasaran perusahaan di bidang pemasaran, setiap perusahaan melakukan kegiatan penyaluran. Penyaluran merupakan kegiatan penyampaian produk sampai ke tangan si pemakai atau konsumen pada waktu yang tepat.

Dalam kegiatan distribusinya perusahaan dapat memperhatikan, pertama, kantor pusat pemasaran, yaitu departemen ekspornya atau divisi yang membuat keputusan mengenai saluran distribusi dan elemen-elemen bauran pemasaran lainnya. Kedua, mengenai jenis-jenis perantaranya, yaitu agen, perusahaan perdagangan dalam hal ini adalah kantor cabang. Letak kantor-kantor cabang yang mudah dijangkau oleh masyarakat dapat mempermudah pendistribusian produk yang ditawarkan kepada nasabah. ${ }^{35}$ Dalam strategi distribusi tempat yang mudah dijangkau oleh

\footnotetext{
${ }^{33}$ Kasmir, Pemasaran Bank, h. 153-154.

${ }^{34}$ Murti Sumarni, Marketing Perbankan, (Yogyakarta: Liberty, 1997), h. 269.

${ }^{35}$ Philip Kotler, Manajemen Pemasaran (Analisis, Perencanaan, Implementasi, dan
} 
nasabah merupakan hal yang penting. Karena dapat menghemat waktu dan biaya dalam menjangkau kantor atau perusahaan yang menawarkan suatu produk yang dibutuhkan oleh nasabah.

Keempat, promotion (promosi). Promosi merupakan kegiatan bauran pemasaran yang terakhir. Promosi berarti aktivitas yang menkomunikasikan keunggulan produk dan membujuk pelanggan sasaran untuk membelinya. ${ }^{36}$ Kegiatan ini setiap perusahaan berusaha untuk mempromosikan seluruh produk dan jasa yang dimilikinya baik langsung maupun tidak langsung.

Dalam Islam mempromosikan suatu barang diperbolehkan. Hanya saja dalam berpromosi tersebut mengedepankan faktor kejujuran dan menjauhi penipuan. Disamping itu, metode yang dipakai dalam promosi tidak bertentangan dengan syariah Islam. ${ }^{37}$

Secara garis besar ada tiga macam sarana promosi yang dapat digunakan oleh perusahaan, yaitu: ${ }^{38}$

Pertama, Periklanan (Advertising). Merupakan promosi yang dilakukan dalam bentuk tayangan atau gambar atau kata-kata yang tertuang dalam spanduk, brosur, koran, majalah, televisi, atau radio.

Kedua, Publisitas (publicity). Merupakan promosi yang dilakukan untuk meningkatkan citra perusahaan di depan para calon nasabah atau nasabahnya melalui kegiatan sponsorship terhadap suatu kegiatan amal atau sosial.

Ketiga, Penjualan Pribadi. Merupakan promosi yang dilakukan melalui pribadi-pribadi karyawan setempat dalam melayani serta ikut mempengaruhi nasabah.

Strategi promosi adalah sesuatu yang dapat memperkenalkan atau mensosialisasikan produk yang ditawarkan suatu perusahaan melalui berbagai macam media dan cara. Tetapi dalam mempromosikan suatu produk harus mengedepankan kejujuran dan menjauhi unsur penipuan.

Pengendalian), (Jakarta: Lembaga Penerbit FEUI, 1993), Vol. II ed. Ke-7, h. 181.

${ }^{36}$ Kotler, Dasar-dasar Pemasaran, h. 49.

${ }^{37}$ Firdaus, Dasar \& Strategi Pemasaran Syariah, h. 27.

${ }^{38}$ Kasmir, Pemasaran Bank, h. 176-177. 


\section{Sejarah Singkat Pegadaian Syariah}

Pegadaian merupakan lembaga perkreditan dengan sistem gadai untuk pertama kalinya. Hadir di Indonesia pada abad ke-17 yang dibawa dan dikembangkan oleh maskapai perdagangan dari negeri Belanda yaitu V.O.C (Vereenigde Oost Indische Compagnie). Dalam rangka memperlancar kegiatan perekonomiannya, pada tanggal 20 Agustus 1746 V.O.C melalui surat keputusan Gubernur Jenderal Van Imhoff didirikanlah pegadaian yang bernama Bank van Leening. Lembaga tersebut merupakan lembaga kredit yang memberikan pinjaman uang kepada masyarakat dengan jaminan gadai. Sejak itu, bentuk usaha pegadaian telah mengalami beberapa kali perubahan sejalan dengan perubahan peraturan-peraturan yang mengaturnya. ${ }^{39}$

Pada masa selanjutnya, pegadaian mengalami beberapa kali perubahan bentuk badan hukum, yaitu pada tahun 1969 Perusahaan Negara Pegadaian diubah menjadi Perusahaan Jawatan (Perjan) Pegadaian, dan pada tahun 1990 Perusahaan Jawatan Pegadaian diubah menjadi Perusahaan Umum (Perum) Pegadaian melalui Peraturan Pemerintah (PP) nomor 10 tahun 1990 tanggal 10 April $1990 .^{40}$ Seiring dengan dikeluarkannya fatwa DSNMUI tentang haramnya riba maka Perum Pegadaian meresponnya dengan mendirikan Unit Layanan Gadai Syariah (ULGS) sebagai diversifikasi produk gadai. Hal tersebut bukan semata-mata respon terhadap fatwa DSNMUI, melainkan dalam rangka membentengi pegadaian sendiri terhadap persaingan dari perbankan syariah. Perbankan syariah pun telah gencar meluncurkan produk serupa berkat pertolongan dari Undang-undang No. 10 Tahun 1998 tentang perbankan syariah, yang isinya menyatakan perbankan syariah boleh mendirikan usaha rahn (gadai). ${ }^{41}$

Bank Muamalat Indonesia dalam mengembangkan usahanya mencoba untuk membuat produk gadai syariah, namun karena tidak mempunyai sumber daya manusia dan peralatan yang cukup memadai, kemuadian Bank Muamalat Indonesia mengajak Perum Pegadaian untuk

${ }^{39}$ Pirgong Matua, Sejarah Singkat Perum Pegadaian, (Jakarta: Perum Pegadaian, 2003), h.1.

${ }^{40}$ Ibid., h.3.

${ }^{41}$ Perum Pegadaian, Manual Operasional Gadai Syariah, (Jakarta: Perum Pegadaian, 2003) 
bekerja sama mendirikan Pegadaian Syariah. Tawaran tersebut mendapat tanggapan yang positif dari Perum Pegadaian yang juga sedang mempelajari pembentukan pegadaian syariah.

Pada tahun 2002 nota kesepakatan kerja sama dibuat antara Perum Pegadaian dengan Bank Muamalat Indonesia. Pada tanggal 20 Desember 2002 penandatanganan kerja sama dilakukan dengan Nomor 446/Sp 300.233/2002 dan 015/BMI/PKS/XII/2002. Bank Muamalat Indonesia menandatangani kerja sama dengan Perum Pegadaian untuk tambahan modal, dengan bentuk pembiayaan musyarakah sejumlah Rp. 40.000.000.000,-. Kemudian pada tanggal 14 Januari 2003 secara resmi dibentuk pegadaian syariah dengan nama Unit Layanan Gadai Syariah (ULGS) dan operasionalnya Dewan Direksi Perum Pegadaian Nomor: 06.A/UL.3.00.22.3/2003 tentang pemberlakuan Manual Operasional Unit Layanan Gadai Syariah. ${ }^{42}$

Pada tahun 2008 kontrak kerja sama dengan Bank Muamalat Indonesia dihentikan. Uang modal yang dipinjam dalam bentuk pembiayaan musyarakah telah dikembalikan. Kini Perum Pegadaian bekerja sama dengan Bank Syariah Mandiri dengan tambahan modal yang diberikan sebesar kurang lebih Rp. 50.000.000.000. Bank Syariah Mandiri menawarkan harga yang lebih miring sehingga pemotongan tarif ijarah dapat dilakukan. ${ }^{43}$

Pembentukan pegadaian syariah ini juga berdasarkan pada fatwa DSN No.25/DSN-MUI/III/2002 tentang rahn dan fatwa DSN No.26/DSN-MUI/ III/2002 tentang rahn emas. Konsep operasi pegadaian syariah mengacu pada sistem administrasi modern, yaitu azas rasionalitas, efisiensi, dan efektifitas yang diselaraskan dengan nilai Islam. Fungsi operasi pegadaian syariah itu sendiri dijalankan oleh Kantor-kantor Cabang Pegadaian Syariah / ULGS sebagai unit organisasi dibawah binaan Divisi Usaha Lain Perum Pegadaian. Namun, baru pada awal tahun 2004 Perum Pegadaian memisahkan Pegadaian Syariah kedalam divisi tersendiri yaitu Divisi Usaha Syariah serta menjadikan setiap cabangnya sebagai binaan Kantor Wilayah (Kanwil) Perum Pegadaian. Selain itu, Perum Pegadaian juga

\footnotetext{
${ }^{42}$ Pegadaian Syariah, Manual Operasional ULGS, Jakarta.

${ }^{43}$ Wawancara dengan Ahmad Zainuddin selaku Manajer Pegadaian Syariah Cabang Dewi Sartika, Jakarta, 12 September 2008.
} 
telah memiliki Dewan Pengawas Syariah (DPS) sendiri yang berguna untuk memberikan pengarahan dan pengawasan terhadap kehalalan produk yang diluncurkan. ${ }^{44}$

Pegadaian syariah pertama kali berdiri di Jakarta pada tanggal 14 Januari 2003 dengan nama Unit Layanan Gadai Syariah (ULGS) Cabang Dewi Sartika, yang terletak di Jalan. Dewi Sartika No.129A Jakarta Timur. Bulan Januari 2003 menyusul kemudian pendirian ULGS di Surabaya, Makasar, Semarang, dan Yogyakarta, di tahun yang sama hingga September 20034 kantor cabang pegadaian di Aceh dikonversi menjadi pegadaian syariah. Istilah ULGS kemudian berubah menjadi Cabang Pegadaian Syariah (CPS). ${ }^{45}$ Saat ini sudah ada 10 CPS dibawah binaan kanwilut (Kantor Wilayah Utama) Jakarta, yaitu CPS Dewi Sartika, CPS Cinere, CPS Pondok Aren, CPS Margonda, CPS Bogor Baru, CPS Kramat Raya, CPS Cipinang Elok, CPS Islamic Centre, CPS Kepandean, dan CPS Kebon Jati.

\section{Visi dan Misi}

Visi Pegadaian: "Pegadaian pada tahun 2010 menjadi perusahaan modern, dinamis, inovatif dengan usaha utama gadai". Dari visi pegadaian di atas dapat dijelaskan artinya sebagai berikut: Modern, dilihat dari kondisi, sarana dan prasarana sistem kerja. Sebagaimana halnya sebuah perkantoran yang modern. Modern juga diartikan mampu menghasilkan produk atau jasa yang sesuai dengan kebutuhan masyarakat modern atau mampu memberi solusi bagi masalah ekonomi masyarakat yang hidup di zaman modern seperti sekarang ini. Dinamis, dicerminkan dari sikap dan perilaku seluruh pegawai dalam hal kecepatan pelayanan dan kemampuan menyesuaikan diri dengan perusahaan yang tertumpu pada peningkatan keterampilan, sikap yang lebih komunikatif, efisien, dan integritas yang tinggi. Dinamis juga berarti harus semakin mampu merespon dengan cepat kebutuhan konsumen baik internal maupun eksternal. Inovatif, tercermin dari kemampuan perusahaan dalam menyempurnakan produk yang sudah ada dana menciptakan berbagai macam produk-produk baru yang

\footnotetext{
${ }^{44}$ Ibid.

${ }^{45}$ Ibid.
} 
menguntungkan. Selain itu, sistem dan prosedur harus selalu diperbaiki dan disempurnakan. Oleh karenanya, dimasa depan pegadaian diharapkan dapat tumbuh dan berkembang menjadi perusahaan yang solid.

Misi Pegadaian: "Ikut membantu program pemerintah dalam upaya meningkatkan kesejahteraan masyarakat golongan menengah kebawah, melalui kegiatan utama berupa penyaluran kredit gadai dan melakukan usaha lain yang menguntungkan". ${ }^{46}$

\section{Budaya Perusahaan}

Pegadaian syariah di dalam tindakan operasionalnya sehari-hari mempunyai budaya perusahaan yang diaktualisasikan ke dalam bentuk simbol atau maskot si INTAN yang bermakna:

Inovatif : : Penuh gagasan (kreatif), aktif, dan menyukai tantangan.

Nilai moral tinggi : Taqwa, jujur, berbudi luhur, dan royal.

Terampil : Menguasai pekerjaan, tanggap, cepat, dan akurat.

Adi layanan $\quad$ : Sopan, ramah, berkepribadian dan simpatik.

Nuansa citra : Berorientasi bisnis, mengutamakan kepuasan pelanggan untuk selalu berusaha mengembangkan diri.

Makna yang terkandung dalam maskot si INTAN adalah: Kepala yang berbentuk berlian memberi makna bahwa pegadaian mengenal batu intan sudah puluhan tahun. Intan tidak lebih dari sebuah bongkahan batu yang diciptakan alam dari sebuah proses yang memakan waktu ratusan tahun lamanya. Kekerasannya menjadikan ia tidak dapat tergores dari benda lain. Tetapi ia juga dapat dibentuk menjadi batu yang sangat cemerlang (brilliant).

Dengan kecemerlangan itulah, kemudian ia disebut berlian. Karakteristik batu intan itudiharapkan terdapat juga di dalam setiap insan pegadaian. Sikap tubuh dengan tangan terbuka dan wajah tersenyummemberi makna sikap seorang pelayan yang selalu siap memberikan pelayanan prima kepada siapa saja. Sedangkan rompi warna hijau memberikan makna keteduhan sebagai insan pegadaian.

${ }^{46}$ Perum Pegadaian, Pedoman Operasional Gadai Syariah, h. I.E.1 


\section{Struktur Organisasi}

Pegadaian Syariah Cabang Dewi Sartika yang terletak di Jalan. Dewi Sartika No.129A Jakarta Timur merupakan tingkatan kantor cabang kelas III yang masih dibina oleh Kantor Wilayah Perum Pegadaian sesuai dengan tempat kedudukan kantor cabang tersebut. Struktur organisasi Kantor Cabang Pegadaian Syariah adalah sesuai dengan Surat Keputusan Direksi Perum Pegadaian No. 1095/SDM.200322/2004, tanggal 28 April 2004, antara lain:47

Manajer Cabang, bertugas mengelola operasional cabang yaitu menyalurkan uang pinjaman (Qardh) secara hukum gadai yang didasarkan pada penerapan prinsip syariat Islam. Disamping itu, Pimpinan Cabang juga melaksanakan usaha-usaha lain yang telah ditentukan oleh manajemen serta mewakili kepentingan perusahaan dalam hubungan dengan pihak lain.

Penaksir, bertugas menaksir marhun (barang jaminan) untuk menentukan mutu dan nilai barang sesuai dengan ketentuan yang berlaku dalam rangka mewujudkan petetapan taksiran dan uang pinjaman yang wajar serta citra baik perusahaan.

Kasir, bertugas melakukan penerimaan, penyimpanan, dan pembayaran serta pembukuan sesuai dengan ketentuan yang berlaku untuk kelancaran pelaksanaan operasional Kantor Cabang.

Pemegang Gudang, bertugas melakukan pemeriksaan, penyimpanan, pemeliharaan dan pengeluaran serta pembukuan marhun selain barang kantong sesuai dengan peraturan yang berlaku dalam rangka ketertiban dan keamanan serta keutuhan marhun.

Penyimpan Marhun, bertugas mengelola gudang marhun emas dengan menerima, menyimpan, merawat, mengeluarkan, dan mengadministrasikannya sesuai dengan ketentuan yang berlaku dalam rangka mengamankan serta menjaga keutuhan barang milik rahin (Penggadai). Keamanan, bertugas mengamankan harta perusahaan dan rahin dalam lingkungan kantor dan sekitarnya. Staf, bertugas memelihara kebersihan, keindahan, kenyamanan gedung ruang kerja, mengirim dan mengambil surat/dokumen untuk menunjang kelancaran tugas administrasi dan tugas operasional Kantor Cabang.

${ }^{47}$ Ibid. 


\section{Produk-produk yang Dihasilkan}

Pertama, ar-Rahn (Gadai Syariah). Usaha pokok dari kegiatan Pegadaian Syariah adalah menyalurkan Marhun bih dalam jumlah skala kecil dengan jaminan harta bergerak maupun tidak bergerak atas dasar hukum gadai Islam. Hal ini sesuai dengan Fatwa Dewan Syariah Nasional No. 25/DSN-MUI/ III/2002 tentang Rahn, tanggal 26 Juni 2002, ${ }^{48}$ dan No. 26/DSN-MUI/II/2002 tentang Rahn Emas, tanggal 28 Maret 2002. ${ }^{49}$ Dimana Rahin menyerahkan harta bergerak/tidak bergerak sebagai jaminan sekaligus memberi kuasa kepada pegadaian syariah untuk menjual/melelang (secara syariah) jika setelah jatuh tempo rahin tidak mampu/bersedia melunasinya. Hasil lelang digunakan untuk melunasi pinjaman pokok ditambah jasa simpan dan biaya lelang. Kelebihannya diserahkan kepada rahin, sedangkan kalau kurang menjadi resiko pegadaian.

Gadai Syariah merupakan produk dengan menggunakan sistem penyaluran pinjaman secara gadai yang didasarkan pada penerapan sistem syariah Islam. Nasabah tidak dikenai bunga pinjaman ataupun sewa modal atas pinjaman yang diberikan. Nasabah dikenakan biaya administrasi dan jasa simpan yang dipungut dengan alasan agunan yang diserahkan nasabah wajib disimpan, dirawat, dan diasuransikan.Pegadaian Syariah Cabang Dewi Sartika sementara hanya menerima barang jaminan berupa emas/ perhiasan. Hutang dapat diangsur sesuai kemampuan dan masa simpan dapat diperpanjang dengan membayar jasa simpan dan bea administrasi. ${ }^{50}$

Kedua, ar-Rahn.(Ar-Rahn Untuk Usaha Mikro Kecil). Pegadaian Syariah merupakan suatu institusi yang mengelola usaha gadai, tetapi lebih luas dari itu menjadi institusi yang mengelola usaha pembiayaan mikro kecil berbasis sistem syariah. Sebagai langkah awal untuk mengimplementasikan gagasan ini, maka skim pembiayaan dengan sistem Ar-Rahn, kini mulai dicoba untuk dikembangkan dengan konsep pelunasan pinjaman secara angsuran baik dengan cara gadai (menahan agunan) maupun fidusia (hanya dokumen kepemilikan barang yang ditahan).

${ }^{48}$ Ahmad Kamil dan M. Fauzan, Kitab Undang-Undang Hukum Perbankan dan Ekonomi Syariah, (Jakarta: Kencana, 2007), h. 545.

${ }^{49}$ Ibid., h. 559.

${ }^{50}$ Perum Pegadaian, Manual Operasional Gadai Syariah, Jakarta. 
Ar-Rahn untuk usaha mikro kecil, selanjutnya disebut skim ARRUM adalah skim pemberian pembiayaan berprinsip syariah bagi para pengusaha mikro dan kecil untuk keperluan usaha yang didasarkan atas kelayakan usaha. Surat Edaran (SE) No. 14/US.200/2008 tentang Penyaluran Pembiayan ARRUM. Tujuan diluncurkannya pembiayaan Arum disamping sebagai sebuah upaya diversifikasi produk di Pegadaian Syariah juga dengan maksud meningkatkan pemberdayaan para pengusaha mikro dan kecil yang membutuhkan pembiayaan modal kerja atau investasi secara syariah. Pembiayaan diberikan dalam jangka waktu tertentu dengan pengembalian pinjaman dilakukan secara angsuran dengan menggunakan konstruksi penjaminan secara gadai maupun fidusia. Skim ARRUM ini merupakan pinjaman kepada individual pengusaha mikro kecil..$^{51}$

\section{Strategi Pemasaran Produk Gadai Syariah}

Perum Pegadaian merupakan Badan Usaha Milik Negara yang bergerak dalam bidang jasa keuangan non perbankan dengan kegiatan usaha utama menyalurkan kredit kepada masyarakat berdasarkan hukum gadai. Pegadaian merupakan salah satu alternatif pendanaan yang sangat efektif karena tidak memerlukan persyaratan rumit yang dapat menyulitkan nasabah dalam pemberian dana. Cukup dengan membawa barang jaminan yang bernilai ekonomis, masyarakat sudah bisa mendapatkan dana untuk kebutuhannya baik produktif maupun konsumtif.

Ar-Rahn (gadai syariah) merupakan salah satu produk unggulan dari pegadaian syariah. Ar-Rahn adalah skim pinjaman untuk memenuhi kebutuhan dana bagi masyarakat dengan sistem gadai yang sesuai syariah Islam dengan agunan berupa emas, berlian, elektronik, dan kendaraan bermotor. Namun demikian, setiap usaha yang dilakukan oleh pegadaian syariah untuk memasarkan produknya dengan apa yang direncanakan merupakan bagian dari strategi pemasaran. Salah satu hal yang paling mendasar dan sangat diperlukan dalam strategi pemasaran adalah bagaimana cara dan upaya untuk menarik minat nasabah sekaligus mempertahankan nasabah tersebut agar tetap setia dan loyal. Oleh karena itu didalam menyusun rencana pemasaran produk gadai syariah, pegadaian

${ }^{51}$ Perum Pegadaian, Manual Operasional Arum, Jakarta 
syariah menempatkan pengenalan produk terhadap calon nasabah pada urutan pertama guna memberikan pelayanan yang sebaik-baiknya kepada nasabah tersebut. Hal ini dilakukan untuk menentukan terlebih dahulu segmen pasar yang akan dituju. Setelah menentukan segmen pasar yang dituju, maka tahap selanjutnya pegadaian syariah memilih pasar sasaran yang ingin dipenuhi kebutuhannya. Pemilihan pasar sasaran produk gadai syariah adalah kepada nasabah potensial, diantaranya adalah nasabah yang memerlukan dana cepat untuk kebutuhan perdagangan, pendidikan, pertanian, perumahan, kesehatan, dan konsumsi.

\section{Penutup}

Berdasarkan pembahasan yang telah dikemukakan di dalam bab-bab sebelumnya mengenai Strategi Pemasaran yang dilakukan oleh Pegadaian Syariah Cabang Dewi Sartika terhadap produk Gadai Syariah, maka dapat ditarik kesimpulan sebagai berikut: Peratama, strategi pemasaran produk gadai syariah yang dilakukan oleh Pegadaian Syariah Cabang Dewi Sartika meliputi empat variabel dalam bauran pemasaran, yaitu: Pertama dengan strategi produk, dengan cara pengembangan produk menjadi ARRUM (Ar-Rahn Untuk Usaha Mikro Kecil) dan pengoptimalan taksiran. Kedua, dengan strategi harga, yaitu dengan memotong tarif ijarah dari Rp.85 menjadi Rp.80 setiap Rp.10.000 nilai taksiran. Ketiga, dengan strategi distribusi, yaitu dilakukan dengan cara membuka UPC (Unit Pelayanan Cabang) kecil agar mudah dijangkau oleh nasabah. Keempat, dengan strategi promosi, yaitu dilakukan dengan cara periklanan, berupa leaflet, brosur, spanduk, souvenir. Publisitas, dengan mengadakan kegiatan amal berupa sunatan masal pada ulang tahun pegadaian. Dan melalui penjualan pribadi dengan cara sosialisasi dengan ibu-ibu pengajian dan melalui pribadi karyawan untuk mempromosikan produk tersebut.

Kedua, implementasi strategi pemasaran yang dilakukan oleh Pegadaian Syariah Cabang Dewi Sartika ternyata mampu menarik minat nasabah, ini terbukti dengan peningkatan jumlah uang pinjaman/omset dan jumlah barang jaminan yang dimiliki Pegadaian Syariah Cabang Dewi Sartika. Peningkatan omzet Pegadaian Syariah Cabang Dewi Sartika adalah sebesar 21,25\% pada periode Januari-Juni 2007 ke periode Juli-Desember 2007 yakni dari Rp. 19.751.000.000 menjadi Rp. 23.949.000.000 dan pe- 
ningkatan sebesar 38,2\% pada periode Juli-Desember 2007 ke periode Januari-Juni 2008 yakni dari Rp. 23.949.000.000 menjadi Rp. 33.100.000.000. Serta peningkatan omzet sebesar 67,5 \% pada periode Januari-Juni 2008 yakni Rp. 33.100.000.000 dibandingkan periode sama tahun 2007, yakni sebesar Rp. 19.751.000000.

Dari kesimpulan yang telah dikemukakan di atas, penulis mencoba untuk memberikan saran bahwa hendaknya Pegadaian Syariah semakin aktif untuk meningkatkan inovasi dalam kegiatan pemasaran, baik promosi dan sosialisasi, karena kegiatan pemasaran terbukti mampu meningkatkan jumlah nasabah. Namun jika dilihat dari persentase peningkatan jumlah nasabah dari tahun ke tahun dirasakan masih belum berhasil secara maksimal. Oleh karena itu perlu diadakan evaluasi terhadap pelaksanaan aktivitas promosi dan sosialisasi secara terus menerus untuk mengetahui seberapa efektif keberhasilan strategi pemasaran yang dilakukan, mengatasi berbagai kendala yang timbul dan sebagai bahan acuan perencanaan kegiatan promosi dan sosialisasi di masa mendatang.

Kemampuan Sumber Daya Manusia perlu lebih ditingkatkan lagi baik melalui pendidikan dan pelatihan yang diberikan serta penyeleksian calon karyawan baru dalam rangka memperbaiki dan meningkatkan profesionalitas kerja pegadaian syariah.

Evaluasi juga perlu dilakukan dengan mendengarkan masukan yang diberikan oleh para nasabah sebagai upaya untuk membangun hubungan kekerabatan silaturahmi antara pegadaian syariah dengan para nasabahnya. Hal ini akan menciptakan kesan positif sekaligus bagian dari sosialisasi pemahaman, pengetahuan, dan pengenalan produk.

\section{Pustaka Acuan}

Al-Qur'an Al-Karim

Ali, Muhammad. Kamus Lengkap Bahasa Indonesia Modern. Jakarta: Pustaka Amani. 1996.

Arifin, Zainul. Dasar-dasar Manajemen Bank Syariah. Jakarta: Alvabet, 2002. Assauri, Sofjan. Manajemen Pemasaran: Dasar, Konsep, dan Strategi. Jakarta: PT. Raja Grafindo Persada, 2004.

Basyir, Ahmad Azhar. Riba, Utang-Piutang, dan Gadai. Bandung: Al-Ma'arif, 1983. 
Al-Bukhari. Shahih Bukhari. Beirut: Maktabah Ashriyah, 1997.

Dzajuli, A dan Aen, Nurol, Ushul Fiqh Metodologi Hukum Islam, Jakarta: PT. Raja Grafindo Persada, 2000.

Firdaus NH, Muhammad. Mengatasi Masalah dengan Pegadaian Syariah. Jakarta: Renaisan, 2005.

------, Cara Mudah Memahami Akad-akad Syariah. Jakarta: Renaisan, 2005.

------, Dasar dan Strategi Pemasaran Syariah, Jakarta: Renaisan, 2005.

Furchan, Ali. Pengantar Metode Penelitian Kualitatif. Surabaya: Usaha Nasional, 1992.

" Gadai Emas Bank Syariah: Barang Aman, Uang di Tangan", http://www. prospektif.com/terkini/artikel.Html?id=969, 1 November 2002.

Hasan, M. Ali. Berbagai Macam Transaksi dalam Islam, (Fiqh Muamalat). Jakarta: PT Raja Grafindo Persada, 2004.

Hendra, Teguh dan Ronny. A Rusli. Manajemen Pemasaran: Analisis, Perencanaan, Implementasi dan Kontrol. Jakarta: PT. Prenhallindo, 1997. Kamil, Ahmad dan Fauzan, M. Kitab Undang-undang Hukum Perbankan dan Ekonomi Syariah. Jakarta: Kencana, 2007.

Kartajaya, Hermawan dan Sula, M. Syakir. Syariah Marketing. Bandung: Mizan, 2006.

Kasmir. Pemasaran Bank. Jakarta: Kencana, 2004.

Kotler, Philip. Marketing. Jakarta: Erlangga, 2004.

--------. Manajemen Pemasaran (Analisis, Perencanaan, Implementasi, dan Pengendalian). Jakarta: FEUI, 1993.

Kotler dan Amstrong. Dasar-dasar Pemasaran. Jakarta: Indeks, 2003.

-------. Prinsip-prinsip Pemasaran. Jakarta: Erlangga, 2001.

Kitab Undang-undang Hukum Perdata (Burgerlijk Wetboek). Penerjemah R. Subekti dan R. Tjitrosudibio. Jakarta: Pradnya Paramita, Cet. VIII, Pasal 1150, 1976.

Al-Mashur Bissayyiri Al-Bakri, Al-Alamah Abi Bakri. Kitab Ia'Natut Tholibin, Beirut: Daarul Fikr, 2004. Juz 3.

Matua, Pirgong. Sejarah Singkat Perum Pegadaian. Jakarta: Perum Pegadaian, 2003.

Moleong, Lexy J. Metodologi Penelitian Kualitatif. Bandung: PT Remaja Rosda Karya, 2002. 
Munawwir, A. W. Kamus Al-Munawwir. Surabaya: Pustaka Progressif, 1997. Muslehuddin, Muhammad. Sistem Perbankan dalam Islam. Jakarta: PT. Rineka Cipta, 2004.

Pandia, Frianto, dkk. Lembaga Keuangan. Jakarta: PT. Rineka Cipta.

Pegadaian Syariah. Manual Operasional ULGS. Jakarta.

"Perbedaan Gadai dengan Rahn" diakses pada 28 Agustus 2008 dari www. pnm.co.id/content.asp?id $=524 \&$ mid $=54-23$ -

"Pertumbuhan Pegadaian Syariah Memuaskan", http://www.republika. co.id/koran detail.asp?id=183268\&kat id2=, 8 Januari 2005.

Perum Pegadaian. Keputusan Direksi Perum Pegadaian tentang Pemberlakuan Manual Operasi Unit Layanan Gadai Syariah, Kep. Dir Perum Pegadaian Nomor. 06.A/UL.3.00.22.3/2003 Ps 1 ayat (1).

-------. Manual Operasional Gadai Syariah. Jakarta: Perum Pegadaian, 2003.

-------. Manual Operasional Arrum.

-------. Pedoman Operasional Gadai Syariah.

Sabiq, Sayid. Fiqh Sunnah. Bandung: PT. Al-Ma'arif, 1996.

Ash-Shiddieqy, Hasbi. Pengantar Fiqh Muamalah. Jakarta: Bulan Bintang, 1984. Stanton, William J. Prinsip-prinsip Pemasaran. Jakarta: Erlangga, 2004. Sukandarrumidi, Metodologi Penelitian (Petunjuk Praktis untuk Peneliti Pemula). Yogyakarta: UGM Press, 2004.

Syafi'i Antonio, Muhammad. Bank Syariah dari Teori ke Praktik. Jakarta: Gema Insani. 2001.

Sudarsono, Heri. Bank dan Lembaga Keuangan Syariah. Yogyakarta: Ekonisia, 2003.

Suhendi, Hendi. Fiqh Muamalah. Jakarta: PT Raja Grafindo Persada, 2007. Sumarni, Murti. Marketing Perbankan. Yogyakarta: Liberty, 1997.

Tjiptono, Fandy. Strategi Pemasaran. Yogyakarta: Andi Press, 2001.

Wasito, Hermawan. Pengantar Metodologi Penelitian. Jakarta: PT Gramedia Pustaka Utama, 1993.

Wawancara dengan Ahmad Zainuddin. Jakarta. 12 September 2008.

Wawancara dengan Supriyono, Jakarta. 29 Agustus 2008.

Zainuddin, Ahmad.. "Omzet Pegadaian Syariah Cawang” artikel diakses pada 28 Agustus 2008 dari Republika Online, http://www.republika.co.id. 